\title{
Regulation of conceptus development and attachment in pigs
}

\author{
R. D. Geisert ${ }^{1}$ and J. V. Yelich ${ }^{2}$ \\ ${ }^{1}$ Animal Science Department, Oklahoma State University, Stillwater, OK 74078, USA; and \\ ${ }^{2}$ Department of Animal Science, University of Florida, Gainesville, FL 3261, USA
}

Implantation/placentation in domestic pigs is preceded by synthesis of oestrogen by the conceptus to maintain functional corpora lutea throughout pregnancy and a rapid morphological transformation of conceptuses from spherical to long filamentous thread-like structures. Initial conceptus expansion, reaching a metre in length, not only delineates the surface area for placental attachment, but also provides the mechanism for delivery of oestrogen to signal events necessary for placentation throughout the uterine horn. Timing for conceptus gene expression to induce trophoblast expansion and attachment in pigs is temporally associated with downregulation of progesterone receptors and increase in oestrogen receptors within the uterine epithelium. Within the confines of the uterine lumen, pig conceptuses normally do not erode or invade through the uterine epithelial surface. However, the pig conceptus possesses extensive proteolytic activity as it is highly invasive outside the uterine lumen of the pig. Initial release of oestrogen by the elongating pig conceptus induces endometrial release of cytokines and a variety of protease inhibitors. Recently, endometrial expression for the inter-trypsin inhibitor (I $\alpha \mathrm{I})$ family of protease inhibitors has been detected in the pig endometrium during conceptus elongation and attachment. It is possible that I Is may function to inhibit trophoblast invasion and also serve as targets for adhesion molecules, such as integrins and heparin, to aid in placental attachment to the uterine epithelium.

\section{Introduction}

There are few mammalian species in which early embryonic development can compare with the rapid alteration in conceptus morphology that occurs during establishment of pregnancy in pigs. During the period of maternal recognition of pregnancy, pig conceptuses undergo a phenomenal morphological change from $10 \mathrm{~mm}$ spherical to tubular $(20-40 \mathrm{~mm})$ and finally filamentous $(100 \mathrm{~mm}$ in length) shapes in less than 3-4 h (Anderson, 1978; Geisert et al., 1982; Stroband and Van der Lende, 1990). Transformation from spherical to a filamentous thread-like morphology occurs through cytoskeletal reorganization which induces cellular modifications in shape and migration, rather than an increase in mitotic activity (Geisert et al., 1982; Mattson et al., 1990). Initial expansion of the pig trophoblast establishes boundaries for placental attachment and initial allotment of uterine space available to each conceptus to compete for nutrients necessary for growth and survival to term. It not only delineates the surface area for placental attachment, but it also provides the mechanism for delivery of conceptus oestrogen throughout the uterus to maintain functional corpora lutea during pregnancy (see reviews Bazer et al., 1984; Geisert et al., 1994a).

Inclusive of maternal recognition on days 10-12 of pregnancy, events critical for early pig embryonic survival include rapid trophoblast elongation, conceptus attachment to the uterine epithelial surface and inhibition of immune rejection by the maternal system. Uterine and conceptus factors involved with inducing rapid trophoblast elongation are of critical importance for embryonic survival. Trophoblast elongation involves many embryonic factors as well as presentation of uterine adhesion factors on the apical border of the endometrial surface epithelium. Initially, uterine 


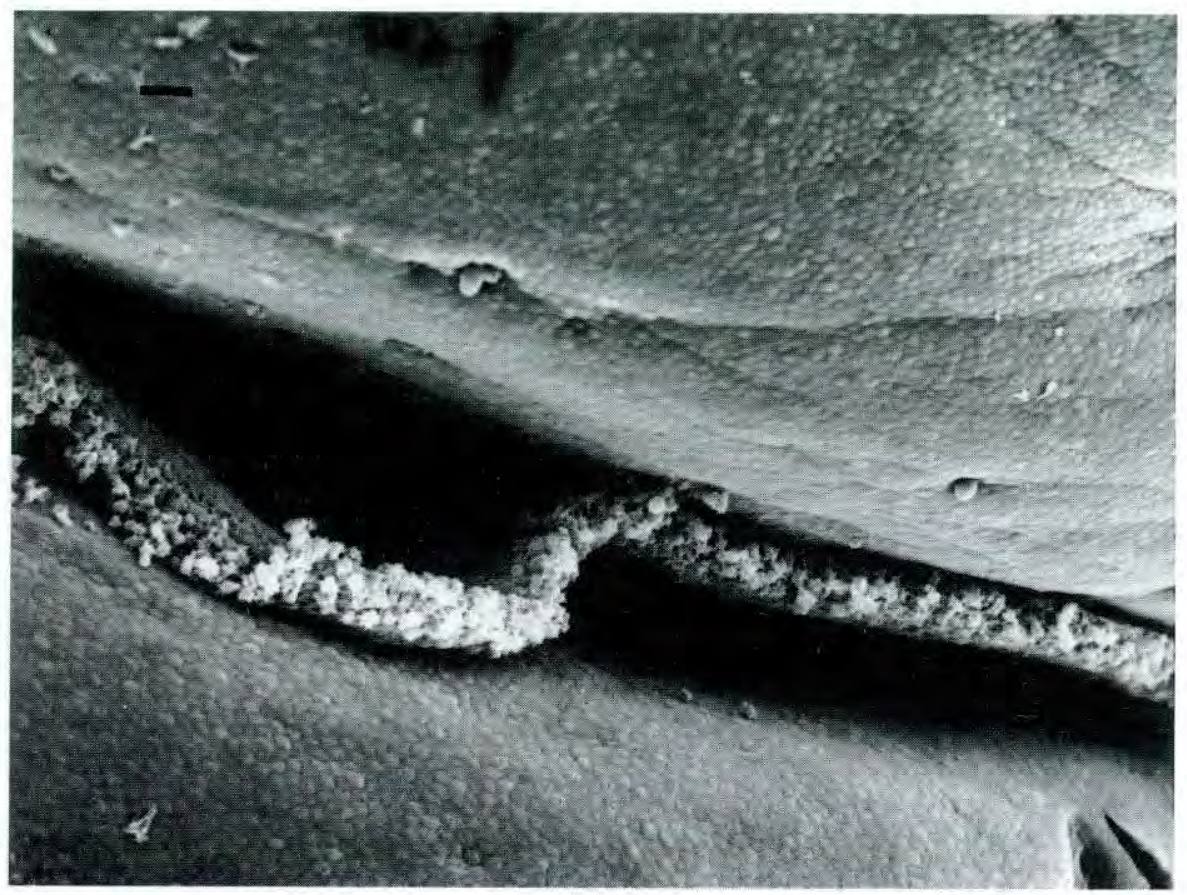

Fig. 1. Scanning electron micrograph showing contact of the elongated pig conceptus apposed to the uterine surface epithelium on day 14 of pregnancy. Scale bar represents $50 \mu \mathrm{m}$.

adhesion to the surface epithelium permits trophoblast elongation throughout the uterine lumen (Fig. 1) and then continuous adhesive attachment of the placenta throughout gestation (King et al., 1982). The alterations within the uterine surface glycocalyx that allow trophoblast elongation and then permanent placental attachment are as critical to conceptus survival as the conceptus factors stimulating the morphological changes in the conceptus. Resolving the conceptus and uterine factors involved with trophoblast elongation and attachment within the confines of the pig uterine lumen would clarify our understanding of embryonic survival in pigs. The present paper will review recent literature concerning conceptus and uterine factors involved with trophoblast development and initial attachment to the uterine surface epithelium.

\section{Conceptus Elongation within the Uterus}

A critical period of embryonic loss occurs when the peri-implantation conceptus undergoes rapid differentiation and expansion of its trophoblastic membrane between days 11 and 12 of gestation (Geisert et al., 1982; Barends et al., 1989; Pope, 1994). Thus, trophoblast elongation is sensitive to changes in the uterine luminal environment that can be influenced by littermate embryos (Pope, 1994). On day 7-8 of pregnancy, the pig blastocyst is composed of an outer layer of polarized trophectoderm, embryonic disc and an inner layer of endodermal cells (see Stroband and Van der Lende, 1990). By day 10 , the pig conceptus expands to a $1-3 \mathrm{~mm}$ sphere before enlarging to a $3-8 \mathrm{~mm}$ ovoid shape at a rate of approximately $0.3 \mathrm{~mm} \mathrm{~h}^{-1}$ over the next $30 \mathrm{~h}$. Once conceptus diameter reaches $9-10 \mathrm{~mm}$, the conceptus rapidly $\left(30-45 \mathrm{~mm} \mathrm{~h}^{-1}\right)$ undergoes a transition to a tubular (12-30 $\mathrm{mm}$ ) and finally thin filamentous form measuring more than $100 \mathrm{~mm}$ in length (Geisert et al., 1982). Perry (1981) compared elongation by the ovoid conceptus to rolling a ball of plasticene under your hand. He suggested that the rapidity of elongation would more likely be explained by deformation 
than by cell division. As predicted by Perry, rapid morphological changes in the pig conceptus are not the result of cellular hyperplasia as proliferative activity, measured by DNA and mitotic index, significantly declines during transition from spherical to filamentous morphology (Geisert et al., 1982; Pusateri et al., 1990). Rather, trophoblastic elongation occurs through massive cellular remodelling of the trophectoderm and endoderm.

Conceptus elongation requires a mechanical force to generate the cellular restructuring necessary to transform its morphology rapidly as the trophectoderm expands. Mattson et al. (1990) proposed that actin filaments may be involved with rearrangement of the trophectoderm plasma membrane and initiate the force necessary for conceptus elongation. Modifications of filamentousactin (f-actin) are consistent with alterations in trophectoderm morphology for axial elongation and narrowing of the conceptus diameter. Polygonal trophectodermal cells of tubular conceptuses vary in the distribution of $\mathrm{f}$-actin in regions proximal to and distal to the embryonic disc. Numerous constricted regions have been observed along the length of the filamentous conceptus (Mattson $e t$ al., 1990). Morphology of trophectoderm cells within the constricted region and the distinct arrangement of f-actin suggest that these cells may generate a contractile force to elongate. Although changes in endodermal ultrastructure have been documented (Geisert et al., 1982; Mattson et al. 1987), regulation of extraembryonic endoderm migration and function during trophoblast expansion have not been determined.

Currently, the factor(s) that initiates elongation and the cytoskeletal processing that dictates the morphological changes in the pig conceptus is coming under intensive study. It is clear that the force necessary for trophoblast elongation originates within the individual conceptus as a mixture of spherical, tubular and elongating conceptuses which can be found within the same litter (Heuser and Streeter, 1929; Anderson, 1978; Geisert et al., 1982). Moreover, when oestrogen is administered to advance the uterine secretory response before conceptus elongation, conceptuses do not elongate until they have reached the $9-10 \mathrm{~mm}$ ovoid morphology (Morgan et al., 1987). Conceptus elongation is, therefore, programmed through developmental cues rather than through direct stimulation by uterine secretions; however, uterine secretions do play a significant role in conceptus growth and survival. The importance of the $10 \mathrm{~mm}$ ovoid stage in conceptus development could be related to differentiation and expansion of the extraembryonic mesoderm (Patten, 1931; Geisert et al., 1982; Gupta et al., 1996). First detection of mesoderm is temporally associated with the initial capacity of the 5-6 mm conceptuses to synthesize oestrogens (Fischer et al., 1985; Pusateri et al., 1990; Wilson and Ford, 1997). Protein and gene expression for steroidogenic enzymes such as $\mathrm{P} 45017 \alpha$-hydroxylase and aromatase are consistent with the increase in conceptus oestrogen synthesis (Conley et al., 1994; Ko et al., 1994; Green et al., 1995; Yelich et al., 1997a; Wilson and Ford 1997). Later, expansion of the extraembryonic mesoderm between the trophectoderm and endoderm at the $10 \mathrm{~mm}$ stage of development may direct cellular remodelling for trophoblast elongation. Certainly, there are many uterine and conceptus factors that contribute to the growth, differentiation and elongation of pig conceptuses.

\section{Endometrial Contributions to Conceptus Development}

Although rapid trophoblast elongation is programmed through developmental cues by the conceptus (Morgan et al., 1987), uterine secretions play a significant role in conceptus growth and survival. A number of the major components of progesterone-stimulated uterine secretions during the oestrous cycle and following conceptus oestrogen release have been reviewed by Davis and Blair (1993) and Roberts et al. (1993a,b), and will only be briefly addressed here. Notably, endometrial synthesis of uteroferrin and retinol-binding protein (RBP) have been studied extensively in pigs. Uteroferrin was one of the earliest uterine proteins identified within the pig uterus (see Roberts $e$ al., 1993a). Although uteroferrin plays a role in iron transport to the fetus throughout pregnancy, evidence has indicated that uteroferrin may also serve as a haematopoietic stem cell growth factor during early conceptus development (Bazer et al., 1991; Michel et al., 1992).

Endometrial secretion of retinol-binding protein (RBP) may function in the transport and delivery of maternal plasma retinol to the developing conceptus (Trout et al., 1992; Harney et al., 
$1994 a, b)$. Uterine secretion of retinol bound to RBP permits the uptake and cellular delivery of retinol to the conceptus through cellular RBP (CRBP) (Napoli et al., 1991). Cytosolic retinol can then be metabolized to retinal and the most biologically active metabolite, retinoic acid (Ross, 1991). Retinoic acid binds directly to retinoic acid receptors (RAR) in the nucleus where it effects gene transcription (Chambon et al., 1991). Harney et al. (1994a) indicated that the components for retinol transport, metabolism and receptor activation are present in endometrial and conceptus tissues during early pregnancy. Pig endometrial and conceptus tissues synthesize RBP, CRBP, RAR $\alpha$ and RAR y during early conceptus development (Trout et al., 1992; Harney et al., 1994a). In fact, RBP is one of the earliest secretory proteins detected in the spherical conceptus on days 10-11 of gestation (Harney et al., 1990). Both uterine and conceptus RBP deliver retinol to tissues, and buffer tissues from the teratogenic (Lammer et al., 1985) and embryotoxic (Thompson et al., 1993) effects of retinoids. Vallet et al. (1996) also proposed a role for RBP in protecting uterine and developing conceptus tissues from the lipid oxidizing activity of uteroferrin. Effects of retinoic acid on components of the extracellular matrix (see De Luca, 1991), cell surface adhesive molecules (Agura et al., 1992), and expression of growth factors and their receptors (Roberts and Sporn, 1988) provide an attractive model for its possible involvement with rapid trophoblast elongation and conceptus development in pigs.

In addition to uteroferrin and RBP, the pig endometrium contains many enzymes such as lysozyme, leucine-aminopeptidase (Roberts et al., 1976; Hansen et al., 1985), $\beta$-hexosaminidase (Hansen et al., 1985), cathepsins B, D, E (Roberts $e t$ al, 1976) and L (Geisert $e t$ al., 1997). Secretion of enzymes such as lysozyme can serve a bactericidal function and for selective proteolysis of proteins for conceptus uptake (Roberts et al., 1993a). Cathepsins are lysosomal cysteine proteases that have been implicated as modulators of invasive implantation of rats (Elangovan and Moulton, 1980) and cats ( $\mathrm{Li}$ et al., 1992). Cathepsin L activity in the pig uterus is induced by progesterone and increases at the time of trophoblast elongation with peak activity on day 15 of pregnancy (Geisert et al., 1997). Although the pig forms a diffuse, epitheliochorial type of placental attachment (King et al., 1982), the high affinity of cathepsin L for collagen (Kirschke et al., 1982) and elastin (Mason et al., 1982) suggests that it may play a role in placental attachment on day 13-18 of gestation through limited proteolysis of the uterine epithelial surface glycocalyx. Uterine growth and expansion during early pregnancy involves elastase activity and collagen remodelling (Renegar, 1982) in which cathepsin L could play a role in both uterine and placental development.

The pig conceptus is normally noninvasive within the confines of the uterine lumen. However, the pig conceptus possesses extensive invasive activity outside the uterine lumen (Samuel and Perry, 1972). Trophoblast secretion of plasminogen activator at the time of elongation can stimulate the release of plasmin through cleavage of plasminogen which is present in the uterine lumen at the time of implantation/placentation (Fazleabas et al., 1983). Generation of plasmin by the pig conceptuses can activate latent forms of other proteases involved with regulation of the cell basement membrane and extracellular matrix (Werb et al., 1980). Association of plasminogen activator with cellular migration and remodelling of various tissues (Bode and Dziadek, 1979) suggests a primary role for plasmin in the remodelling of the conceptus (Fazleabas et al., 1983). The release of plasmin into the uterine lumen would represent a by-product of conceptus development which must be controlled to avoid damage to the uterine luminal epithelium.

Endometrial secretion of a variety of protease inhibitors regulates the microenvironment during placental attachment in pigs (see Roberts et al., 1993a). The pig endometrium secretes a protease inhibitor specific for plasmin, chymotrypsin and trypsin during the period of trophoblast elongation and placentation (Fazleabas et al., 1983). This inhibitor contains a kunitz domain which provides inhibitory activity against serine proteases (Stallings-Mann et al., 1994). Expression of a uterine elastase/cathepsin $G$ protease inhibitor, antileukoprotinease, during pregnancy in pigs may also support and maintain the noninvasive, epitheliochorial placenta throughout pregnancy (Simmen $e t$ al., 1992a). In addition, the pig uterus also secretes a group of low molecular mass, basic proteins that are related to the 'serpin family' of protease inhibitors (Murray et al., 1989; Malathy et al., 1990).

Recently, expression of the inter-trypsin inhibitor (I $\alpha$ I) family of protease inhibitors was detected in the pig endometrium during conceptus elongation and attachment (Geisert et al., 1996; Diederich 
et al., 1997). Inter-trypsin inhibitors are plasma serine protease inhibitors that have been described during the acute phase reaction to cardiogenic shock (see Salier et al., 1996). The family of intertrypsin inhibitors are interesting in that they are synthesized as precursor polypeptides that give rise to mature chains with distinct functions and form inter-chain glycosamino-glycan bonds with various molecules. The inter-trypsin inhibitor family of serine protease inhibitors can consist of either a combination of two heavy chains $I \alpha I H 1, I \alpha I H 2$ and a single light chain known as bikunin, $\mathrm{I} \alpha \mathrm{IH} 3$ and bikunin or $\mathrm{I} \alpha \mathrm{IH} 2$ and bikunin (see review Salier et al., 1996). Heavy chains of I $\alpha \mathrm{IH} 1$, $\mathrm{I} \alpha \mathrm{IH} 2$ and $\mathrm{I} \alpha \mathrm{IH} 3$ form the various complexes with bikunin through binding to a chrondroitin sulfate chain (Enghild et al., 1993). All the serine protease inhibitory activity is attributed to bikunin, as it contains two Kunitz-type serine protease inhibitor domains (Hochstrasser et al., 1981). Bikunin originates from a separate mRNA in which $\alpha-1$-microglobulin and bikunin are synthesized as single proteins which undergo proteolytic cleavage (Kaumeyer et al., 1986). However, the I $\alpha \mathrm{I}$ heavy chains are translated from separate mRNAs (Diarra-Mehrpour et al., 1989). Through its tandemly arranged kunitz domains, bikunin can target inhibition of trypsin, cathepsin G, elastase and plasmin. The biological role of the I $\alpha$ I family as protease inhibitors is under investigation (Salier et al., 1996). Previously, it was proposed that synthesis of the inter-trypsin inhibitors was restricted to the liver (Saguchi et al., 1995). Uterine synthesis of inter-trypsin inhibitors could regulate conceptus attachment and limit proteolysis. Certainly, bikunin can assist with regulation of endometrial invasion by the pig trophoblast as endometrial bikunin gene and protein expression are detected from day 12 to day 18 of pregnancy (Diedrich et al., 1997). However, it is possible that the heavy chains of I $\alpha$ may function in the initial attachment of the conceptus to the uterine epithelial surface as will be addressed later.

Continuous growth, development and differentiation of pig conceptuses are highly dependent upon the timing and quantitative amounts of growth factors secreted into the uterine lumen. Insulin-like growth factor I (IGF-I) is one of the earliest and most completely characterized of the growth factors identified in uterine secretions of pigs (Simmen et al., 1993). As endometrial IGF-I expression reaches peak values during conceptus elongation and oestrogen release on day 12 of gestation (Letcher et al., 1989; Simmen et al., 1992b), uterine secretion of IGF-I may enhance conceptus oestrogen synthesis (Hofig et al., 1991), possibly through the enhancement of P450 aromatase gene expression (Ko et al., 1994; Green et al., 1995). The IGF-I receptor mRNA is constitutively expressed during early conceptus development (Green et al., 1995); however, trophectoderm IGF-I receptor protein content is low (Chastant et al., 1994). Uterine secretion of IGFI may play more of an autocrine role in uterine growth and development as the endometrium contains an abundance of IGF-I receptors (Simmen et al., 1992b; Chastant et al., 1994). Trophectoderm of developing conceptuses expresses IGF-II/mannose 6-phosphate receptor which may stimulate conceptus growth and differentiation (Chastant et al., 1994). However, expression of endometrial IGF-II mRNA increases on day 15 (Simmen et al., 1992b), which is several days after conceptus elongation. It is possible that uterine IGF-I effects early conceptus growth and development by binding to the IGF-II receptor (Czech, 1986). Targeted mutagenesis of the IGF-II/mannose-6phosphate receptor gene in the mouse has demonstrated its importance in early embryonic survival (Barlow et al., 1991). Since mutation of either IGF-I, IGF-II or IGF-I receptor only reduce prenatal growth (DeChiara et al., 1990; Liu et al., 1993), it is possible that one receptor can substitute for loss of another. Newton $e$ t al. (1994) indicated that the oestrogen receptor can be transcriptionally activated through IGF-I intracellular signalling suggesting that the oestrogen receptor is one of the nuclear factors involved with growth stimulation. It is possible that conceptus oestrogen and uterine IGF-I coordinate uterine growth and development during trophoblast elongation.

Interest in the role of growth factors in pig conceptus and uterine development has led to identification of a host of growth factors within the uterus (Table 1). Epidermal growth factor (EGF), heparin-binding EGF (HB-EGF), transforming growth factor $\alpha$ (TGF- $\alpha$ ) and amphiregulin, all of which bind and activate the EGF receptor (Prigent and Lemoine, 1992), are expressed by the pig endometrium during early pregnancy (Brigstock et al., 1990; Kennedy et al., 1994; Kim et al., 1995; Brigstock et al., 1996a,b). Both EGF and HB-EGF have been immunolocalized to the surface and glandular epithelium of the endometrium (Kennedy et al., 1994; Kim et al., 1995) and the luminal 
Table 1. Growth factor and receptor expression by the pig endometrium during early conceptus development and placentation

\begin{tabular}{|c|c|c|}
\hline Expression & Developmental process affected & Reference \\
\hline $\begin{array}{l}\text { Insulin-like growth factors } \\
\text { (IGF) }\end{array}$ & $\begin{array}{l}\text { Regulation of cellular } \\
\text { proliferation and differentiation }\end{array}$ & $\begin{array}{l}\text { Letcher et al., } 1989 \\
\quad \text { Green } \text { et al., } 1995 \\
\text { Simmen } \text { et al., } 1992\end{array}$ \\
\hline $\begin{array}{l}\text { Insulin-like growth factor } \\
\text { receptor }\end{array}$ & $\begin{array}{l}\text { Receptor activation for cellular } \\
\text { proliferation and differentiation }\end{array}$ & Green et al., 1995 \\
\hline $\begin{array}{l}\text { Insulin-like growth factor } \\
\text { binding protein } 2\end{array}$ & $\begin{array}{l}\text { Regulation of IGF-I and JGF-II } \\
\text { activity }\end{array}$ & Șimmen et al., 1992 \\
\hline $\begin{array}{l}\text { Epidermal growth factor } \\
\text { (EGF) }\end{array}$ & $\begin{array}{l}\text { Regulation of cellular } \\
\text { proliferation and differentiation }\end{array}$ & Kennedy et al., 1994 \\
\hline $\begin{array}{l}\text { Heparin binding-epidermal } \\
\text { growth factor (HB-EGF) }\end{array}$ & $\begin{array}{l}\text { Regulation of cellular } \\
\text { proliferation and differentiation }\end{array}$ & $\begin{array}{l}\text { Brigstock et al., } 1990 \\
\quad \text { Kim et al., } 1995\end{array}$ \\
\hline $\begin{array}{l}\text { Epidermal growth factor } \\
\text { receptor }\end{array}$ & $\begin{array}{l}\text { Receptor activation by EGF, } \\
\cdot \text { HB-EGF, TGF and amphiregulin }\end{array}$ & $\begin{array}{l}\text { Zhang et al., } 1992 \\
\text { Kennedy et al., } \\
1994\end{array}$ \\
\hline $\begin{array}{l}\text { Transforming growth factor- } \alpha \\
\text { (TGF } \alpha)\end{array}$ & $\begin{array}{l}\text { Regulation of cellular } \\
\text { proliferation and differentiation }\end{array}$ & $\begin{array}{l}\text { Vaughan et al., } 1992 \\
\text { Kennedy et al., } 1994\end{array}$ \\
\hline Transforming growth factor $-\beta 3$ & $\begin{array}{l}\text { Chemoattractant } \\
\text { regulates cellular differentiation } \\
\text { and morphogenesis } \\
\text { Collagen and fibronectin gene } \\
\text { expression }\end{array}$ & $\begin{array}{l}\text { Sun et al., } \\
\text { unpublished results }\end{array}$ \\
\hline Keratinocyte growth factor & $\begin{array}{l}\text { Heparin-binding growth factor } \\
\text { Mediates effecis of progesterone } \\
\text { and androgen on epithelium }\end{array}$ & Liu et al., 1995 \\
\hline $\begin{array}{l}\text { Keratinocyte growth factor } \\
\text { receptor }\end{array}$ & $\begin{array}{l}\text { Receptor activation for stromal } \\
\text { function }\end{array}$ & Tuo et al., 1996 \\
\hline $\begin{array}{l}\text { Retinoic acid receptor- } \alpha \text {, } \\
-\beta,-\gamma\end{array}$ & $\begin{array}{l}\text { Retinoic acid receptor for } \\
\text { uterine development }\end{array}$ & $\begin{array}{l}\text { Harney et al., } 1994 \\
\text { Sun et al., } \\
\text { unpublished } \\
\text { results }\end{array}$ \\
\hline Interleukin 6 & $\begin{array}{l}\text { Uterine immunological stimulation } \\
\text { Uterine hyperaemic response }\end{array}$ & $\begin{array}{l}\text { Mathialagan et al., } \\
1992 \\
\text { Anegon et al., } 1994\end{array}$ \\
\hline Fibroblast growth factors & $\begin{array}{l}\text { Regulation of cellular } \\
\text { proliferation and differentiation }\end{array}$ & Brigstock et al., 1989 \\
\hline Leukaemia inhibitory factor & Regulation of embryo differentiation & Anegon et al., 1994 \\
\hline Colony stimulating factor 1 & $\begin{array}{l}\text { Haematopoietic growth factor } \\
\text { Cellular proliferation and } \\
\text { differentiation }\end{array}$ & Tuo et al. 1995 \\
\hline Pleiotrophin & Neurotrophic factor & Brigstock et al., 1996 \\
\hline
\end{tabular}

content of EGF in uterine secretions is increased on day 12 of pregnancy followed by a decline to day 16 (Diehl et al., 1994). Endometrial and conceptus tissues express EGF receptor (Zhang et al., 1992a,b; Kennedy et al., 1994) which indicates that uterine secretion of EGF and other ligands for EGF receptor could regulate uterine and conceptus development. Although expression of these growth factors, as well as basic fibroblast growth factor (Brigstock et al., 1989) and pleiotrophin (Brigstock et al., 1996a), has been demonstrated, their relationships to conceptus development have not been defined.

In addition to pleiotrophin, several haematopoietic cytokines have been detected within the pig endometrium and uterine secretions during early conceptus development. Given its role as a haematopoietic regulator involved in cellular differentiation and cellular growth, leukaemia inhibitory factor (LIF) is one of the most notable cytokines secreted by pig endometrium at the time 
of conceptus elongation (Anegon et al., 1994). Endometrial gene expression and secretion of LIF into the uterine lumen are maximal on days 11-12 of pregnancy in pigs (Anegon et al., 1994). The essential role of LIF in blastocyst growth and implantation in mice (see Stewart, 1994) implies that LIF may serve a vital function in conceptus development and implantation in pigs. The importance of conceptus growth and differentiation, and possibly of expansion of the extraembryonic mesoderm, provides an attractive model for studies of endometrial LIF regulation of trophoblast elongation and implantation in pigs.

LIF is related to and binds to a receptor common to interleukin 6 (IL-6), and colony-stimulating factor 1 (CSF-1) (Bazan, 1991). Pig endometrium contains mRNA for $\Pi L-6$ and $\Pi-6$ is present within the uterine secretions during the oestrous cycle and early pregnancy (Anegon et al., 1994). However, changes in mRNA and protein are not associated with changes in conceptus development on days 11-12 of pregnancy as observed for LIF. Gene expression and tissue production of CSF-1 have been detected in the pig endometrium and conceptus (Tuo et al., 1995). Immunoreactive CSF-1 is localized in the uterine surface and glandular epithelium on day 10 of pregnancy, but the greatest tissue content and mRNA expression occur after day 30 of gestation. Temporal changes in CSF-1 mRNA and protein in the endometrium and placenta of pigs suggest that CSF-1 may influence placental and fetal growth following implantation/placentation (Tuo et al., 1995).

The pig endometrium has recently been shown to be a source of relaxin (Knox et al., 1994) and oxytocin (Trout et al., 1995). Although the pig corpus luteum has long been known to be an endocrine source of relaxin (Sherwood, 1994), relaxin has now been localized in the uterine surface and glandular epithelium of gilts during the oestrous cycle and early pregnancy (Knox et al., 1994). Intensity of relaxin immunostaining is weak on day 12 but increases to day 16 and expression is maintained to day 20 in pregnant gilts. Detection of mRNA encoding relaxin demonstrated that the endometrium is the source of relaxin in the uterine epithelium (Knox et al., 1994). Relaxin has a definite uterotrophic effect (Galvin et al., 1991) which could stimulate growth of the uterus to accommodate expansion of the allantochorionic membranes from days 18-30 of pregnancy (see Bazer et al., 1981). Oestrogen stimulation of uterine secretions by the elongating conceptus at the time of maternal recognition of pregnancy initiates release of endometrial oxytocin into the uterine lumen (Trout et al., 1995). Endometrial oxytocin mRNA reaches peak values on day 12 of the oestrous cycle or pregnancy (S. Sun, T. Yelich and R. Geisert, unpublished results). Lack of oxytocin receptor mRNA in day 10-12 conceptus tissue (Yelich et al., 1997a) suggests that uterine oxytocin release may have an autocrine function in uterine contraction and closure of the uterine lumen surrounding the developing conceptus, rather than a direct effect on the developing conceptus. High luminal content of oxytocin may also play a role in regulating the movement of prostaglandin $\mathrm{F}_{2 \alpha}$ during maternal recognition of pregnancy (see Bazer et al., 1984).

As described previously, there is a great deal of information on the presence of uterine growth factors which may effect conceptus development, many of which are steroid regulated (IGF-I, IGF-II, LIF, RBP). Timing of uterine growth factor expression and subsequent protein release relative to conceptus development needs to be tightly regulated as the uterine environment is not tolerant of asynchrony in conceptus development (see Pope, 1994). The increase in concentrations of plasma progesterone from the corpora lutea is certainly the primary director of uterine development and secretion. However, the marked changes in uterine epithelial secretions and conceptus elongation in pigs are actually temporally related to downregulation of progesterone receptors in the surface and glandular epithelium from day 10 of the oestrous cycle or pregnancy (Geisert et al., 1994b) and the increase in epithelial oestrogen receptors (Geisert et al., 1993). Thus, the loss of progesterone receptors from the uterine epithelium may play an essential role in the timing of growth factor secretion for the developing conceptus and the responsiveness of uterine epithelium to conceptus oestrogens during trophoblastic elongation and implantation. Stromal cell progesterone receptors are maintained during this period and may stimulate the uterine epithelium by secretion of keratinocyte growth factor (KGF) in response to progesterone (Liu et al., 1995). KGF receptors are expressed constitutively by the uterine epithelium (Liu et al., 1996). Although there are now clues to the regulation of uterine growth factor secretion during early conceptus development, definitive roles for each growth factor in conceptus development need to be established. 
Table 2. Growth factor and receptor expression by the pig conceptus before and during elongation

\begin{tabular}{|c|c|c|}
\hline Expression & Developmental process affected & Reference \\
\hline Brachyury & Mesoderm formation & Yelich et al., 1997a \\
\hline Cytochromes & Steroidogenesis & Conley et al., 1994 \\
\hline $\begin{array}{l}\mathrm{P} 45017_{\alpha} \\
\mathrm{P} 450_{\text {artm }} \\
\mathrm{P} 450\end{array}$ & & $\begin{array}{l}\text { Green et al., } 1995 \\
\text { Corbin et al., } 1996\end{array}$ \\
\hline Insulin-like growth factor I & $\begin{array}{l}\text { Regulation of cellular proliferation } \\
\text { and differentiation }\end{array}$ & $\begin{array}{l}\text { Letcher et al., } 1989 \\
\text { Green } \text { et al., } 1995\end{array}$ \\
\hline $\begin{array}{l}\text { Insulin-like growth factor I } \\
\text { receptor }\end{array}$ & $\begin{array}{l}\text { Regulation of cellular proliferation } \\
\text { and differentiation }\end{array}$ & Green et al., 1995 \\
\hline Insulin-like growth factor II & $\begin{array}{l}\text { Regulation of cellular proliferation } \\
\text { and differentiation }\end{array}$ & Simmen et al., 1992 \\
\hline $\begin{array}{l}\text { Insulin-like growth factor II } \\
\text { receptor }\end{array}$ & $\begin{array}{l}\text { Regulation of cellular proliferation } \\
\text { and differentiation }\end{array}$ & Chastant et al., 1994 \\
\hline Epidermal growth factor & $\begin{array}{l}\text { Regulation of cellular proliferation } \\
\text { and differentiation }\end{array}$ & Vaughan et al., 1992 \\
\hline EGF receptor & $\begin{array}{l}\text { Regulation of cellular proliferation } \\
\text { and differentiation }\end{array}$ & $\begin{array}{c}\text { Vaughan et al., } 1992 \\
\text { Corps et ol., } 1990 \\
\text { Zhang et al., } 1992\end{array}$ \\
\hline Transforming growth factor $\alpha$ & Regulation of cellular morphogenesis & Vaughan et al., 1992 \\
\hline $\begin{array}{l}\text { Transforming growth factor } \beta-1 \text {, } \\
\beta-2, \beta-3\end{array}$ & $\begin{array}{l}\text { Chemoattractant. Regulation of } \\
\text { cellular differentiation and } \\
\text { morphogenesis. Collagen and } \\
\text { fibronectin expression }\end{array}$ & $\begin{array}{l}\text { Yelich et al., 1997a } \\
\text { Cupta et al., } 1996\end{array}$ \\
\hline Retinol-binding protein & Retinol transport to conceptus & $\begin{array}{l}\text { Harney et al., 1990, } \\
\text { 1994b } \\
\text { Trout et al., } 1992 \\
\text { Yelich et al., 1997b }\end{array}$ \\
\hline Retinoic acid receptor- $\alpha,-\beta,-\gamma$ & $\begin{array}{l}\text { Receptor for retinoic acid for embryo } \\
\text { morphogenesis }\end{array}$ & $\begin{array}{l}\text { Harney et al., 1994a } \\
\text { Yelich et al., 1997b }\end{array}$ \\
\hline $\begin{array}{l}\text { Leukaemia inhibiting factor } \\
\text { receptor }\end{array}$ & $\begin{array}{l}\text { Regulation of cellular proliferation } \\
\text { and differentiation }\end{array}$ & Yelich et al., 1997 \\
\hline Interleukin $1 \beta$ & $\begin{array}{l}\text { Uterine immunological stimulation } \\
\text { Haematopoiesis }\end{array}$ & Tuo et al., 1996 \\
\hline Interleukin 6 & Uterine immunological stimulation & $\begin{array}{l}\text { Mathialagan } \text { et al., } \\
1992 \\
\text { Anegon et al., } 1994\end{array}$ \\
\hline Colony stimulating factor 1 & $\begin{array}{l}\text { Cellular proliferation and } \\
\text { differentiation }\end{array}$ & Tuo et al., 1995 \\
\hline Interferons & Immunological regulation & $\begin{array}{l}\text { Lefevre and Boulay, } \\
1993 \\
\text { Cross and Roberts, } \\
1989\end{array}$ \\
\hline
\end{tabular}

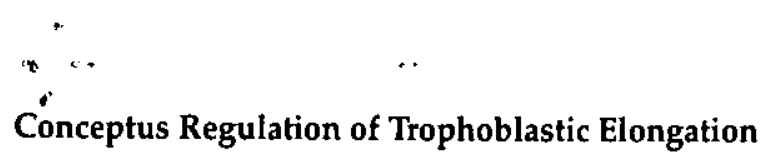

As previously discussed, rapid elongation of the conceptus on days 10-12 of gestation appears to be programmed by endogenous developmental cues. Since conceptuses elongate only after they have reached the $10 \mathrm{~mm}$ morphology (Morgan et al., 1987), the critical period of development may prepare the early spherical $(1-3 \mathrm{~mm})$ and late-spherical $(9-10 \mathrm{~mm})$ conceptuses for elongation. This 
period is characterized by enhanced conceptus gene expression that orchestrates the sequence of cellular events necessary to initiate and allow trophoblast elongation to occur (Table 2).

Synthesis and secretion of oestrogen by the developing pig conceptus is the fundamental marker of trophoblast elongation (see Geisert et al., 1990). Two key enzymes involved in the steroidogenic pathway for oestrogen synthesis in the conceptus are the cytochromes P450 17 $\alpha$-hydroxylase $\left(\mathrm{P}_{50} \mathrm{17 \alpha}_{\mathrm{\alpha}}\right)$ and aromatase ( $\left.\mathrm{P} 450_{\text {arom }}\right)$. Although low, initial expression of $\mathrm{P450} 0_{17 \alpha}$ is detected in conceptuses of less than $6 \mathrm{~mm}$ diameter, and increases as conceptuses approach the large spherical stages $(10 \mathrm{~mm})$ just before elongation. Conceptus $\mathrm{P} 450_{\text {arom }}$ gene expression follows a similar pattern that is greatly enhanced at the time of elongation (Conley et al., 1992, 1994; Ko et al., 1994; Green et al., 1995; Yelich et al., 1997a). Immediately after elongation of the trophoblast, gene expression for both enzymes decreases markedly (King and Ackerley, 1985; Conley et al., 1992; Ko et al., 1994; Green et al., 1995). Oestrogen production by the conceptus has a direct effect on uterine function as evidenced by an abundance of oestrogen receptors in the uterine epithelium at the time of trophoblast elongation (Geisert $e t$ al., 1993) which, when activated, result in the secretion of numerous uterine proteins as previously discussed in this review. Whether there is a direct effect of oestrogen produced by the conceptus on trophoblast elongation is unclear, although it appears unlikely since oestrogen receptors cannot be detected in the early conceptus by either immunocytochemistry or RT-PCR (R.D. Geisert, unpublished results; Yellich et al., 1997a).

Initial synthesis of oestrogen and elongation of the conceptus is closely associated with first detection of mesoderm differentiation in $5 \mathrm{~mm}$ spherical conceptuses that may be the key to the programming of trophoblast elongation (see reviews by Geisert et al., 1990; Stroband and Van der Lende, 1990). The appearance of mesoderm within the embryoblast corresponds to initial expression of the brachyury gene in conceptuses (Yelich et al., 1997a). Brachyury gene expression encodes a transcription factor necessary for mesodermal differentiation in mice (Herrmann et al., 1990), as homozygous mutants for the gene are lethal (Conlon et al., 1995). Brachyury gene expression coincides with and parallels $\mathrm{P}_{450_{17 \alpha}}$ and $\mathrm{P} 450_{\text {arom }}$ gene expression in early spherical conceptuses (Yelich et al., 1997a). Whether or not expression of brachyury, or the subsequent differentiation of mesoderm, initiates steroidogenesis is debatable. Absence of $\mathrm{P}_{50} \mathrm{H}_{17 \alpha}$ and $\mathrm{P} 450_{\text {nrom }}$ gene expression in the mesoderm (Conley et al., 1994) suggests that effects of the mesoderm, if any, on oestrogen synthesis are indirect.

Expression of receptors for LIF, IGF-II and EGF have been described in early developing conceptuses (see Table 2). As previously discussed, the uterus secretes IGF-I, EGF, HB-EGF and CSF1 during conceptus elongation, but these growth factors appear to play more of a supportive role in growth and differentiation rather than in cellular remodelling. Initial expression of LIF receptor is observed in $2 \mathrm{~mm}$ spherical conceptuses, with a marked increase to a peak at the $7 \mathrm{~mm}$ spherical conceptus stage, which is maintained throughout trophoblast elongation (Yelich et al., 1997a). Uterine secretion of LIF at the time of conceptus elongation suggests that LIF may serve a vital function in conceptus development, possibly expansion of the extraembryonic mesoderm, which initiates signalling for remodelling of the trophectoderm. LIF could direct remodelling by enhancing production of conceptus proteases and this is supported by the observation that LIF regulates protease activity in the expanding mouse blastocyst (Harvey et al., 1995). Proteases serve as modifiers of the extracellular matrix (Brenner et al., 1989; Alexender and Werb, 1991).

Expression of mRNA for the EGF receptor has also been detected equally across all stages of preelongated conceptuses (Vaughan et al., 1992). Specific binding of EGF to its receptor was also detected (Zhang et al., 1992b), although binding increased temporally from day 10 to day 13 and increased sixfold by day 15 after elongation. The EGF receptor also binds transforming growth factor $\alpha$ (TGF- $\alpha$ ). This may be significant because expression of conceptus TGF- $\alpha$ mRNA is maximal before and during elongation, and declines during the post-elongation period (Vaughan et al., 1992). Vaughan et al. (1992) speculated that TGF- $\alpha$ plays a role in fluid transport during elongation, and this is supported by the observation that exogenous TGF- $\alpha$ enhances fluid uptake and subsequent blastocoel expansion in the peri-implantation mouse conceptus (Dandick and Schultz, 1991). Whatever role TGF- $\alpha$ may have in conceptus elongation, increased expression of TGF- $\alpha$ could initiate events necessary for rapid trophoblastic elongation, while conceptus EGF gene expression may regulate 


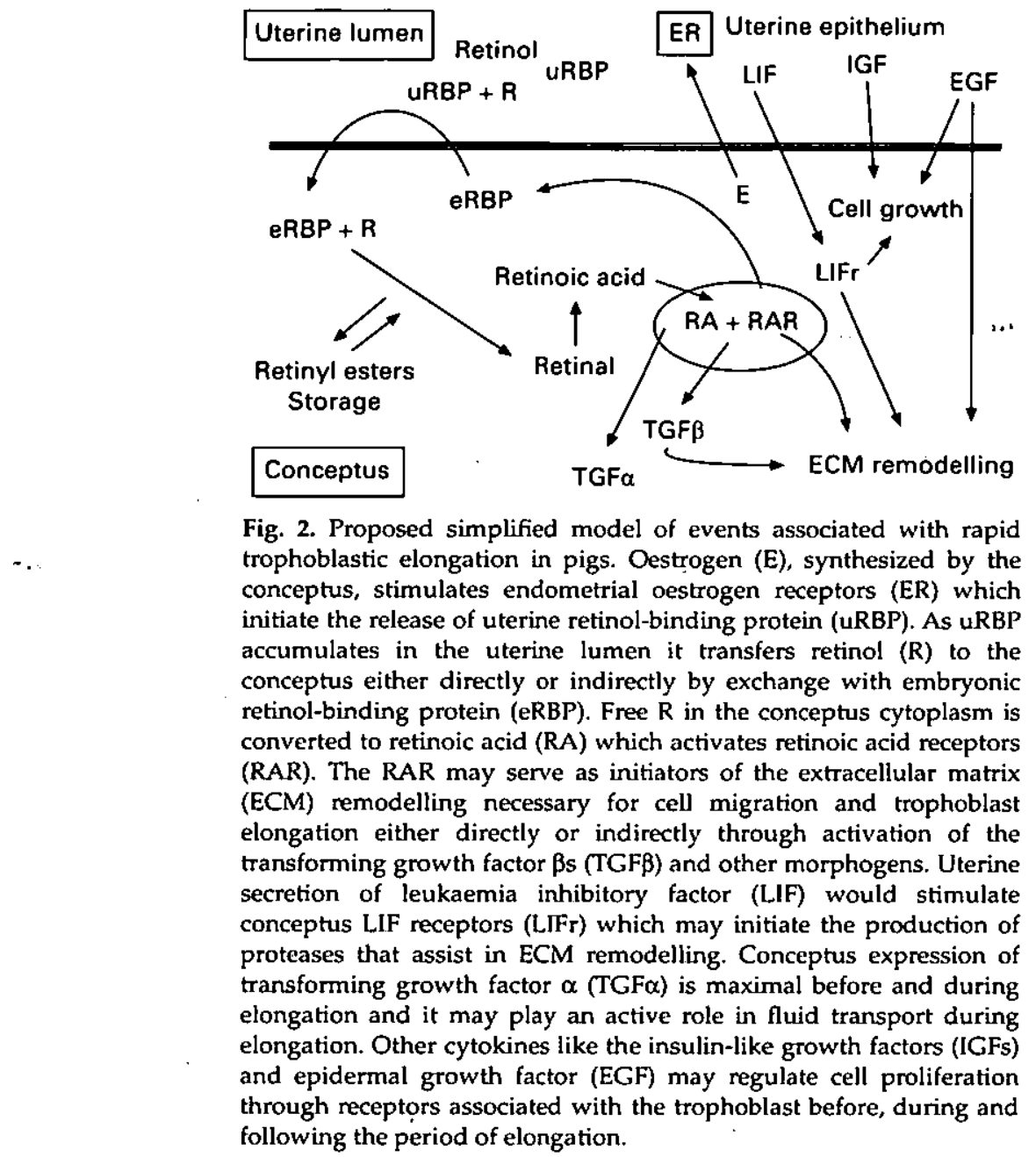

development of the embryo during early placentation. Recently, several members of the transforming growth factor $\beta$ (TGF- $\beta$ ) superfamily and their receptors have been detected in peri-implantation pig conceptuses. Yelich et al. (1997b) observed increased expression of mRNA encoding TGF $\beta-3$ during the period of conceptus elongation, but did not detect expression of TGF $\beta-2$. In a comprehensive study Gupta et al. (1996) found that TGFß-1, TGFß-2 and TGFß-3 were immunohistochemically localized in peri-implantation pig conceptuses as were type I and type II TGF $\beta$ receptors. Gupta et al. (1996) concluded that the TGF 3 s may be involved in induction or advancement of mesoderm migration in developing conceptuses, possibly through regulation of expression of extracellular matrix proteins (Ignotz and Massague, 1986). Laminin and fibronectin are both produced in the early developing pig conceptus (Richoux et al., 1989; Tuo and Bazer, 1996; Bowen et al., 1997).

Several conceptus cytokines may regulate immunofunction within the pig uterus. Interleukin $1 \beta$ (IL-1ß) expression by the early pig conceptus is temporally associated with maternal recognition of pregnancy (Tuo et al., 1996). Conceptus synthesis of IL-1 $\beta$ may play a role in the interplay of the trophoblast and uterus for the establishment of pregnancy through its influence on conceptus remodelling and stimulation of prostaglandin $E$ release. There may be an interaction between oestrogen, PGE, IL-1 $\beta$ and interferon- $\gamma$ (INF- $\gamma$ ), as conceptus INF- $\gamma$ increases on day 13 (see La Bonnardiere, 1993) when $\Pi-1 \beta$ expression has declined (Tuo et al., 1996). 
One of the most promising candidates for activation of trophectoderm remodelling is the cellular morphogen, retinoic acid (Harney et al., 1990). Transport of retinol by RBP into the uterine lumen, as described previously, provides the substrate for retinoic acid to the developing conceptus. Transcripts for RBP have been detected in day 11 pig conceptuses (Trout et al., 1991; Hamey et al., 1994b; Yelich et al., 1997b) consistent with the presence of immunoreactive RBP in early conceptuses (Hamey et al., 1990). Gene expression for RBP is initially observed in $2 \mathrm{~mm}$ conceptuses and increases temporally with peak expression just before the initiation of trophoblast elongation (Yelich et al., 1997b). In contrast, uterine expression of mRNA encoding RBP is very low on days 10 and 11 of pregnancy (Harney et al., 1994b), which is consistent with low uterine content of retinol during this period (Trout et al., 1992). The initial rise in conceptus RBP gene expression could serve to protect the developing conceptus from excessive concentrations of retinol released into the uterine lumen in response to conceptus oestrogen secretion (Harney et al., 1990), and to assist in the distribution of retinol to target tissues in the conceptus (Trout et al., 1991) to stimulate cellular remodelling and elongation. Retinoic acid alters embryonic development in mammals (Tickle et al., 1985), affects gene transcription (Chiocca et al., 1989), influences production of extracellular matrix components (see De Luca, 1991) and cell surface adhesive molecules (Agura et al., 1992), and can induce the expression of several peptide growth factors (Roberts and Sporn, 1988) and their receptors (Jetten, 1980). Retinoids exert their biological effects through RAR within the cell. Harney $e$ t al. (1994a) first described the presence of RAR $\alpha$ and RAR $\gamma$ mRNA and protein in day 15 conceptuses. Yelich et al. (1997b) demonstrated the presence of $R A R \alpha,-\beta$ and $-\gamma$ mRNA during both the pre- and post-elongation periods of conceptus development. Gene expression for RAR $\alpha$ was activated before and during conceptus elongation, in a similar way to TGFß-3 gene expression (Yelich et al., 1997b), whereas RAR expression was more pronounced at the time of trophoblast elongation. It would be expected that RAR would be localized in the trophoblast where RBP is concentrated (Harney et al., 1990; Trout et al., 1992). It is evident that both RBP and RAR may have a role in the initiation or eventual remodelling of the trophoblast during elongation (see model, Fig. 2). Retinoic acid activates expression of laminin $\beta 1$ (Ross et al., 1994), and integrin $\beta$-1 expression (Ross et al., 1994) while it also stimulates gene expression of TGF- $\beta$ s (Roberts and Sporn, 1988). The TGF- $\beta$ s are major modifiers of the ECM, particularly in the case of integrins which bind to numerous ECM proteins (Ignotz and Massague, 1986). The ECM may also be modulated through retinoic acid induced activation of conceptus proteases. Retinoic acid influences the production of the protease urokinase-type plasminogen activator and its respective inhibitor (Tienari et al., 1991), both of which are involved in ECM breakdown. In addition, Adler et al. (1990) suggested that the expression of ECM-degrading metalloproteinases and their inhibitors are developmentally regulated during the differentiation and spreading of the endoderm in embryonal carcinoma cells stimulated to differentiate with retinoic acid.

\section{Kallikrein - a Key to Conceptus-Endometrial Interaction}

Since the time that conceptus oestrogen synthesis was first shown to be involved in establishment of pregnancy in pigs, many alterations in protein secretion, prostaglandin movement, blood flow and changes in uterine morphology have been described (see Geisert et al., 1990). However, the factor(s) induced by conceptus oestrogen to orchestrate these biological changes has not been elucidated. The discovery of the I $\alpha$ I family and a novel inter-trypsin inhibitor H4 produced by the pig endometrium has provided insights to the mechanism whereby conceptus oestrogens regulate uterine function during placentation. Geisert et al. (1995) described changes in an endometrial glycoprotein (GP30) which is associated with the time of conceptus attachment to the uterine surface and conceptus survival. GP30 is homologous to the C-terminal region of a larger (120 $\mathrm{kDa})$ pig plasma glycoprotein, I $\alpha \mathrm{IH} 4$ (Geisert et al., 1996; Hashimoto et al., 1996). Human and pig $\mathrm{I} \alpha \mathrm{IH} 4$ are different from other inter-trypsin inhibitor heavy chains, as the consensus DPHFII sequence for binding to bikunin is absent (Saguchi et al., 1995; Hashimoto et al., 1996). Because IoIH4 does not contain protease inhibitory activity or bind other I $\alpha \mathrm{IH}$ chains, I $\alpha \mathrm{IH} 4$ must have a biological 


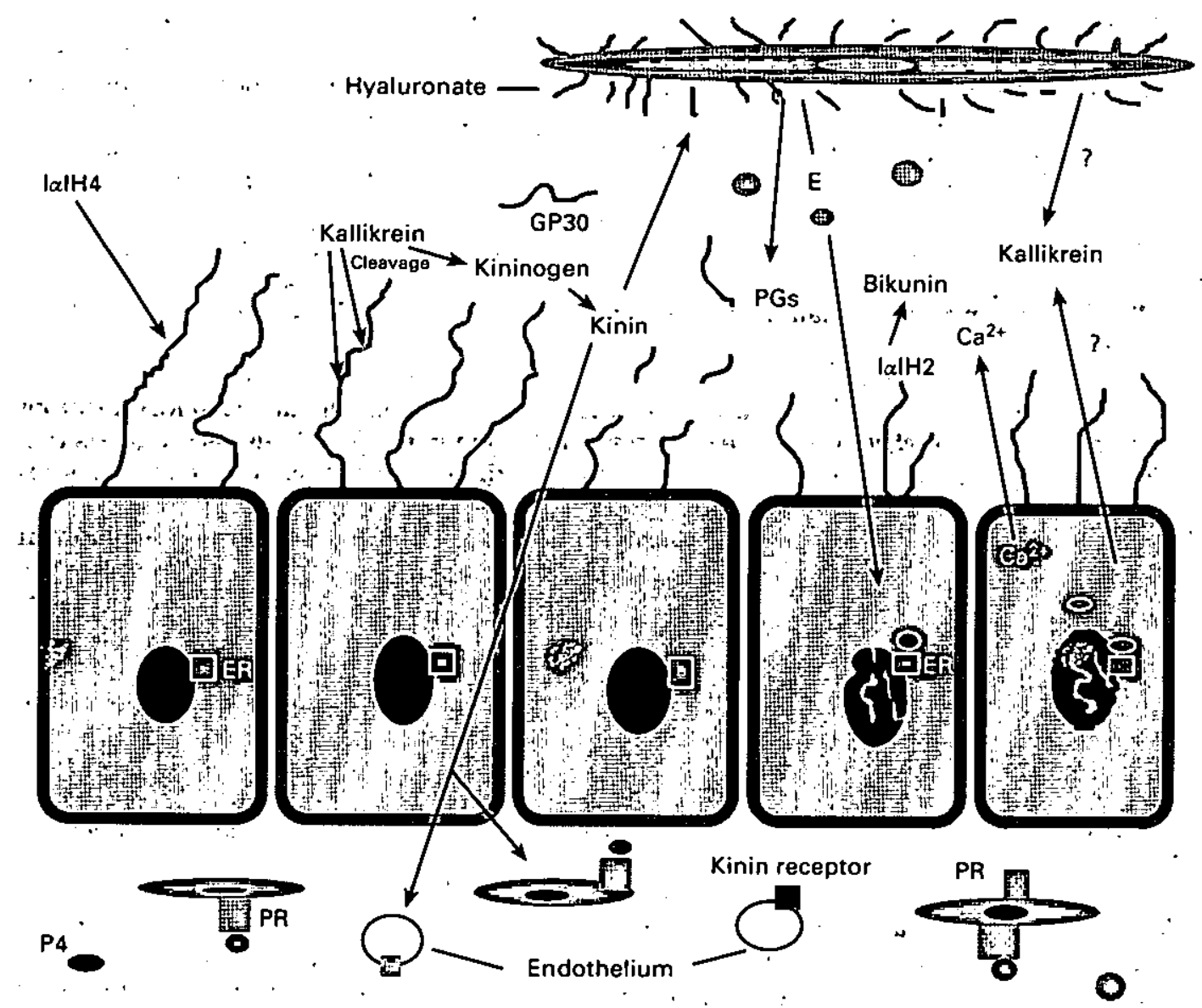

Fig. 3. Proposed model for initial attachment of the conceptus to the uterine epithelium. Release of conceptus oestrogen (E) may stimulate release of uterine kallikrein which acts to cleave inter-trypsin inhibitor heavy chain 4 (I $\alpha \mathrm{IH} 4)$ present on the uterine epithelial surface. Cleavage of lalH4 releases a $30 \mathrm{kDa}$ glycoprotein (GP30) the function of which is unknown and a smaller polypeptide fragment. The N-terminal region of I $\alpha \mathrm{lH} 4$, which contains binding sites for hyaluronate and integrins, remains on the uterine epithelial surface to bind to the conceptus. Presence of kallikrein may also activate cleavage of kininogen to kinin for stimulation of uterine bloodflow, calcium release and prostaglandin synthesis. Detection of IaIH2 and bikunin in the endometrium indicates that the I $\alpha \mathrm{I}$ family of acute phase proteins may regulate uterine inflammation and conceptus invasion through the uterine epithelial surface.

function unrelated to protease inhibition. In contrast to the other I $\alpha$ I heavy chains, plasma human and pig I $\alpha \mathrm{IH} 4$ serve as substrates for the plasma serine protease, kallikrein (Nishimura et al., 1995). Plasma kallikrein first cleaves the $120 \mathrm{kDa}$ I $\alpha \mathrm{IH} 4$ glycoprotein into 100 and $35 \mathrm{kDa}$ fragments, and then further cleaves the $100 \mathrm{kDa}$ protein to a $70 \mathrm{kDa}$ fragment which can release GP30, as observed in the pig endometrium (Geisert et al., 1995).

Heavy chains of inter-trypsin inhibitors contain calcium-binding sites, potential reactive sites as thiol-protease inhibitors (Salier et al., 1987, 1996) and most importantly, associate with hyaluironan (Zhao et al., 1995). Numerous studies have established the relevance of hyaluronic acid (HA) binding to $\mathrm{I} \alpha \mathrm{I}$ heavy chains with cell types that display an HA-containing coat (see Salier et al., 1996). All I $\alpha \mathrm{I}$ heavy chains possess a von Willebrand type A domain that functions as a target for adhesion molecules such as integrins, collagen, proteoglycans and heparin (see Salier et al., 1996). It has been proposed that inter-trypsin inhibitor heavy chains stabilize the extracellular matrix (Chen et al., 1994; 
Jessen et al., 1994). In arthritis, binding of inter-trypsin inhibitor heavy chains to hyaluronate may protect the joint from inflammatory damage possibly caused by free oxygen radicals (Hutadilok $e t$ al., 1988). Hyaluronan, a ubiquitous structure within the tissue extracellular matrix serves many roles in tissue morphogenesis, cell proliferation and cell migration. Therefore, in addition to the possible role of pig endometrial I $\alpha \mathrm{IH} 4$ in trophoblast attachment during pregnancy, the multipolypeptide chain of the pig I $\alpha \mathrm{IH} 4$ could also serve to stabilize the epithelial glycocalyx and protect it from free radical damage. Alteration in I $\alpha \Pi \mathrm{H} 4$ may not be the only factor involved with trophoblast attachment; however, cleavage of $\mathrm{I} \alpha \mathrm{IH} 4$ could induce local alterations in receptivity to the conceptus that permits the conceptus to contact integrins for firm attachment to the uterine epithelium (Bowen et al., 1997). Kallikrein cleaves I $\alpha \mathrm{IH} 4$ to allow interaction of the $55 \mathrm{kDa}$ fragment of I $\alpha \mathrm{IH} 4$ with integrins and HA for placental attachment.

Kallikrein protease activity increases during conceptus elongation and oestrogen secretion (Vonnahme and Geisert, unpublished results), which is associated with alterations in I $\alpha \mathrm{H} 4$ during early pregnancy (Geisert $e t$ al., 1995). The presence of kallikrein in the pig uterus also suggests that the pig uterus may have a functional kallikrein-kininogen-kinin system. A number of physiological responses that occur during early pregnancy in pigs are consistent with functions of bioactive kinins (Margolius, 1996). The pig uterus is responsive to oestrogen during the period of placental attachment and oestrogen stimulates increases in uterine blood flow, vasodilatation of the capillaries surrounding the elongated conceptus, contraction of the myometrium, and endometrial release of calcium, protein and histamine (see Geisert et al., 1990). Kinins have a high affinity for specific membrane receptors on diverse cell types that regulate tissue blood flow, ion transport and smooth muscle contractions (see Bhoola et al., 1992; Rusiniak and Black, 1995; Margolius, 1996). Several studies have demonstrated that the presence of tissue kallikrein in the rat uterus is steroid regulated and correlated with the timing of implantation (Corthorn and Valdes, 1994; Brann et al., 1995; Valdes et al., 1996). These studies suggest that the kallikrein-kininogen-kinin system plays a major role in the induction of the prostaglandin and histamine cascade involved with endometrial permeability and decidual transformation in rats following oestrogen stimulation.

Studies demonstrating a biologically active kallikrein-kininogen-kinin system in the pig uterus during early pregnancy have not been completed; however, we propose that conceptus elongation and oestrogen release initiates a cascade of uterine changes through kallikrein that influence implantation/placentation (see model, Fig. 3). Activation of kallikrein within the uterine lumen would cleave endometrial I $\alpha \mathrm{IH} 4$ and permit conceptus trophoblast adhesion to the uterine surface epithelium during and following conceptus elongation. In addition, kallikrein cleaves kininogen into kinin which functions to increase calcium, protein and proteinase inhibitor release locally into the uterine lumen as well as to increase uterine blood flow and production of postaglandins by the conceptus during trophoblast elongation. The localized stimulation of I $\alpha \mathrm{IH} 4$ and the short half-life of kinins would permit regulation of the uterine environment by each developing conceptus within the uterine horn.

\section{References}

Adler RR, Brenner CA and Werb Z (1990) Expression of extracellular matrix-degrading metalloproteinase and metalloproteinase inhibitors is developmentally regulated during endoderm differentiation of embryonal carcinoma cells Development 110 211-220

Agura ED, Howard $M$ and Collins SJ (1992) Identification and sequence analysis of the promoter for the leukocyte integrin $\beta$-subunit (CD18): a retinoic acid-inducible gene Blood 79 602-609

Alexender $\mathrm{CM}$ and Werb $\mathrm{Z}$ (1991) Extracellular matrix degradation. In Cell Biology of Extracellular Matrix, $\mathrm{pP}$ 255-302 Ed. ED Hay. Plenum Publishing Corp., New York

Anderson LL (1978) Growth, protein content and distribution of early pig embryos Anatonical Record 190 143-154
Anegon I, Cuturi MC, Godard A, Moreau M, Terqui M, MartinatBotte F and Soulillou JP (1994) Presence of leukaemia inhibitory factor and interleukin 6 in porcine uterine secretions prior to conceptus attachment Cytokine $6493-499$

Barends PMG, Stroband HW], Taverne N, te Kronnie G, Leen MPJM and Blommers PCJ (1989) Integrity of the preimplantation pig blastocyst during expansion and loss of polar trophoblast (Rauber cells) and the morphology of the embryoblast as an indicator for developmental stage Joumal of Reproduction and Fertility 87 715-726

Barlow DP, Stoger R, Herrmann BG, Saito K and Schweifer N (1991) The mouse insulin-like growth factor type 2 receptor is imprinted and closely related to the Tme locus Nature 349 84-87 
Bazan JF (1991) Neuropoietic cytokines in the hematopoietic fold Neuron 7 197-208

Bazer FW, Goldstein MH and Barron DH (1981) Water and electrolyte transport by the pig chorioallantois. In Fertilization and Embryonic Development in Vivo, pp 299-321 Eds L Mastroianni, Jr and JD Biggers. Plenum Publishing Corp., New York

Bazer FW, Marengo SR, Geisert RD and Thatcher WW (1984) Exocrine versus endocrine secretion of prostaglandin $F$ in the control of pregnancy in swine Animal Reproduction Science 7 115-132

Bazer FW, Worthington-White D, Fliss MF and Gross S (1991) Uteroferrin: a progesterone-induced hematopoietic growth factor of uterine origin Experimental Hematology 19 910-915

Bhoola KD, Figueroa CD and Worthy K (1992) Bionegulation of kinins: kallikreins, kininogens, and kininases Pharmacological Reviews 44 1-80

Bode VC and Dziadek MA (1979) Plasminogen activator secretion during mouse embryogenesis Developmental Biology 73 272-289

Bowen JA, Bazer FW and Bunghandt RC (1997) Spatial and temporal analyses of integrin and muc-1 expression in porcine uterine epithelium and trophectoderm in vitro. Biology of Reproduction 56 409-415

Brann DW, Greenbaum L, Mahesh VB and Gao X (1995) Changes in kininogens and kallikrein in the plasma, brain, and uterus during pregnancy in the rat Endocrinology 136 46-51

Brenner CA, Adler RR, Rappolee DA, Pederson RA and Werb Z (1989) Genes for extracellular matrix-degrading metalloproteinases and their inhibitor, TIMP, are expressed during early mammalian development Genes and Development 3 848-859

Brigstock DR, Heap RB and Brown KD (1989) Polypeptide growth factors in uterine tissues and secretions Journal of Reproduction and Fertility 85 747-758

Brigstock DR, Heap RB, Baker PJ and Brown KD (1990) Purification and characterization of heparin-binding growth factors from porcine uterus Biochemical Joumal 266 273-282

Brigstock DR, Kim GY and Steffin CL. (1996a) Pig uterine fluid contains the developmentally-regulated neurotrophic factor, pleiotrophin Journal of Endocrinology 148 103-111

Brigstock DR, Kim GY, Steffin CL, Liu A, Vegunta RK and Ismail NH (1996b) High molecular mass forms of epidermal growth factor in pig uterine secretions fournal of Reproduction and Fertility 108 313-320

Chambon P, Zelent A, Petkovich M, Mendelsohn D, Leroy P, Krust A, Kastner $P$ and Brand $N$ (1991) The family of retinoic acid nuclear receptors. In Retinoids: 10 Years On, pp 10-27 Ed. JH Saurat, Karger, Basel

Chastant S, Monget P and Terqui M (1994) Localization and quantification of insulin-like growth factor-I (IGF-I) and IGF-II/mannose-6-phosphate (IGF-II/M6P) receptors in pig embryos during early pregnancy Biology of Reproduction 51 588-596

Chen L, Mao SJT, McLean LR, Powers RW and Larsen WJ (1994) Proteins of the inter- $\alpha$-trypsin inhibitor family stabilize the cumulus extracellular matrix through their direct binding with hyaluronic acid lournal of Biological Chemistry 269 28282-28287

Chiocca EA, Davies PJ and Stein JP (1989) Regulation of tissue transglutaminase gene expression as a molecular model for retinoid effects on proliferation and differentiation Journal of Cell Biochemistry 39 293-304
Conley AJ, Christenson RK, Ford SP, Geisert RD and Mason JI (1992) Steroidogenic enzyme expression in porcine conceptuses during and after elongation Endocrinology 131 896-902

Conley AJ, Christenson RK, Ford SP and Christenson RK (1994) Immunocytochemical localization of cytochrome P450 $17 \alpha$-hydroxylase and aromatase in embryonic cell layers of elongating porcine blastocysts Endocrinology 135 2248-2254

Conlon FL, Wright CV and Robertson EJ (1995) Effects of the TWis mutation on notochord formation and mesodermal patterning Mechanisms of Development 49 201-209

Corthom J and Valdes G (1994) Variations in uterine kallikrein during cycle and early pregnancy in the rat Biology of Reproduction 50 1261-1264

Cross JC and Roberts RM (1989) Porcine conceptuses secrete an interferon during the preattachment period of early pregnancy Biology of Reproduction 40 1109-1118

Czech MP (1986) Structures and functions of the receptors for insulin and the insulin-like growth factors journal of Animal Science 63 (Supplement 2) 27-38

Dardick A and Schultz RM (1991) Blastocoel expansion in the preimplantation mouse embryo: stimulatory effect of TGF$\alpha$ and EGF Development $113919-930$

Davis DL, and Blair RM (1993) Studies of uterine secretions and products of primary cultures of endometrial cells in pigs Journal of Reproduction and Fertility Supplement 48 143-155

DeChiara TM, Efstratiadis A and Robertson EJ (1990) A growthdeficiency phenotype in heterozygous mice carrying an insulin-like growth factor II gene disrupted by targeting Nature 345 78-80

De Luea LM (1991) Retinoids and their receptors in differentiation, embryogenesis, and neoplasia. FASEB 5 2924-2933

Diarta-Mehrpour M, Bourguignon J, Sesboue R, Mattei MG, Passage E, Salier JP and Martin JP (1989) Human plasma inter-alphatrypsin inhibitor is encoded by four genes on three chromosomes European Joumal of Biocitemisty 179 147-154

Diederich MJ, Yelich JV and Geisert RD (1997) Gene and protein expression of the inter-trypsin inhibitor, bikunin, in the porcine conceptus and endometrium Journal of Animal Science 75 (Supplement 1) 83

Diehl JR, Henricks DM and Gray SL (1994) EGF and IGF-1 in the uterine and oviductal fluids of pregnant and nonpregnant pigs from day 10 to day 18 Biology of Reproduction 50 (Supplement 1) 122

Elangovan S and Moulton BC (1980) Blastocyst implantation in the rat and the immunohistochemical distribution and rate of synthesis of uterine lysosomal cathepsin D Biology of Reproduction $23663-668$

Enghild JJ, Salvesen G, Thogersen IB, Valnickova Z, Pizzo SV and Hefta SA (1993) Presence of the proteinglycosaminoglycan-protein covalent crosslink in the interalpha-inhibitor-related proteinase inhibitor heavy chain 2/bikunin Journal of Biological Chemistry $2688711-8716$

Fazleabas AT, Geisert RD, Bazer FW and Roberts RM (1983) Relationship between release of plasminogen activator and estrogen by blastocysts and secretion of plasmin inhibitor by uterine endometrium in the pregnant pig Biology of Reproduction 29 225-238

Fischer HE, Bazer FW and Fields MJ (1985) Steroid metabolism by endometrial and conceptus tissues during early pregnancy and pseudopregnancy in gilts fournal of Reproduction and Fertility 75 69-78 
Galvin JM, Anthony RV and Day BN (1991) Effects of purified porcine relaxin on the uterus of gilts during early pregnancy Animal Reproduction Science 26 293-301

Geisert RD, Renegar RH, Thatcher WW, Roberts RM and Bazer FW (1982) Establishment of pregnancy in the pig. I. Interrelationships between peri-implantation development of the pig blastocyst and the uterine endometrial secretions Biology of Reproduction 27 925-939

Geisert RD, Zavy MT, Moffatt RJ, Blair RM and Yellin T (1990) Embryonic steroids and the establishment of pregnancy Journal of Reproduction and Fertility Supplement 40 293-305

Geisert RD, Brenner RM, Moffatt RJ, Harney JP, Yellin T and Bazer FW (1993) Changes in oestrogen receptor protein, mRNA expression and localization in the endometrium of cyclic and pregnant gilts Reproduction Fertility and Development 5 247-260

Geisert RD, Short EC and Mongan GL (1994a) Establishment of pregnancy in domestic farm species. In Embryonic Mortality in Domestic Species, pp 23-52 Eds MT Zavy and RD Geisert. CRC Press, Boca Raton

Geisert RD, Pratt T, Bazer FW, Mayes JS and Watson CH (1994b) Immunocytochemical localization and changes in endometrial progestin receptor protein during the porcine oestrous cycle and early pregnancy Reproduction Fertility and Development 6 749-760

Geisert RD, MJ Dixon, T Pratt, RAM Schmitt, BA Lessley and JP McCann (1995) Isolation and characterization of a $30 \mathrm{kDa}$ endometrial glycoprotein synthesized during the estrous cycle and early pregnancy in the pig Biology of Reproduction 53 942-954

Geisert RD, Yelich JV, Pratt T and Pomp D (1996) Identification of porcine endometrial CP30 as inter-trypsin inhibitor family heavy chain-related protein Biology of Reproduction 54 (Supplement 1) 78

Geisert RD, Blair RM, Pratt T and Zavy MT (1997) Characterization and proteolytic activity of a cathepsin $L$ like polypeptide in endometrium and uterine flushings of cycling, pregnant and steroid-treated ovariectomized gilts Reproduction Fertility and Development 9 (in press)

Green ML, Simmen RCM and Simmen FA (1995) Developmental regulation of steroidogenic enzyme gene expression in the peri-implantation porcine conceptus: a paracrine role for insulin-like growth factor-I Endocrinology 136 3961-3970

Gupta A, Bazer FW and Jaeger LA (1996) Differential expression of beta transforming growth factors (TGF $\beta 1$, TGF $\beta 2$, and TGFB3) and their receptors (Type I and Type II) in periimplantation porcine conceptuses Biology of Reproduction 55 796-802

Hansen PJ, Bazer FW and Roberts RM (1985) Appearance of $\beta$ hexosaminidase and other lysosomal-like enzymes in the uterine lumen of gilts, ewes, and mares in response to progesterone and cestrogens Journal of Reproduction and Fertility 73 411-424

Harney JP, Mirando MA, Smith LC and Bazer FW (1990) Retinolbinding protein: a major secretory product of the pig conceptus Biology of Reproduction 42 523-532

Hamey JP, Ali M, Vedeckis WV and Bazer FW (1994a) Porcine conceptus and endometrial retinoid-binding proteins Reproduction Fertility and Development 6 211-219

Hamey JP, Smith LC, Simmen RCM, Fliss AE and Bazer FW (1994b) Retinol-binding protein: immunolocalization of protein and abundance of messenger ribonucleic acid in conceptus and maternal tissues during pregnancy in pigs Biology of Reproduction 50 1126-1135
Harvey MB, Leco KJ, Arcellana-Panlilio MY, Zhang X, Edwards DR and Schultz GA (1995) Roles of growth factors during periimplantation development Molecular Human Repraduction $10712-718$

Hashimoto K, Tobe T, Sumiya J, Sano Y, Choi-Miura N, Ozawa A, Yasue $H$ and Tomita M (1996) Primary structure of the pig homologue of human IHRP: inter-trypsin inhibitor family heavy chain-related protein Journal of Biochemistry 119 577-584

Herrmann BG, Labiet S, Poustka A, King TR and Lehrach H (1990) Cloning of the $T$ gene required in mesoderm formation in the mouse Nature $343617-622$

Heuser CH and Streeter GL (1929) Early stages in the development of pig embryos, from the period of initial cleavage to the time of the appearance of limb-buds Contributions to Embryology Carnegie Institute 20 3-29

Hochstrasser K, Schonberger OL, Rossmanith I and Wachter E (1981) Kunitz-type proteinase inhibitors derived by limited proteolysis of the inter-trypsin inhibitor HoppeSeyler's Zeitschrift fiir Physiologische Chemie 362 1357-1362

Hofig A, Simmen FA, Bazer FW and Simmen RCM (1991) Effects of insulin-like growth factor-l on aromatase cytochrome P450 activity and oestradiol biosynthesis in preimplantation poncine conceptuses in vitro. Joumal of Endocrinology 130 245-250

Hutadilok N, Ghosh P and Brooks PM (1988) Binding of haptoglobin, inter-trypsin inhibitor, and $\alpha 1$ proteinase inhibitor to synovial fluid hyaluronate and the influence of these proteins on its degradation by oxygen derived free radicals Annals of Rheumatoid Disease 47 377-385

Ignotz RA, and Massague J (1986) Transforming growth factor- $\beta$ stimulates the expression of fibronectin and collagen and their incorporation into the extracellular matrix Joumal of Biological Chemistry $2614337-4345$

Jessen TE, L Odum and AH Johnsen (1994) In vivo binding of human inter-trypsin inhibitor free heavy chains to hyaluronic acid Biological Chemistry Hoppe-Seyler 375 521-526

Jetten AM (1980) Retinoids specifically enhance the number of epidermal growth factor receptors Nature 284 626-629

Kaumeyer JF, Polazzi JO and Kotick MP (1986) The mRNA for a proteinase inhibitor related to the HI-30 domain of interalpha-trypsin inhibitor also encodes alpha-1microglobulin (protein HC) Nucleic Acids Research 14 7839-7850

Kennedy TG, Brown KD and Vaughan TJ (1994) Expression of the genes for the epidermal growth factor receptor and its ligands in porcine oviduct and endometrium Biology of Reproduction 50 751-756

Kim GY, Besner GE, Steffen CL, McCarthy DW, Downing MT, Luquette MH Abad MS and Brigstock DR (1995) Purification of heparin-binding EGF-like growth factor from pig uterine flushings and its production by endometrial tissues Biology of Reproduction 52 561-571

King GJ and Ackerley CA (1985) Demonstrations of oestrogen in developing pig trophectoderm and yolk sac endoderm between days 10 and 16 Journal of Reproduction and Fertility 73 361-367

King G J, Atkinson BA and Robertson HA (1982) Implantation and early placentation in domestic ungulates foumal of Reproduction and Fertility Supplement 31 17-30

Kirschke H, Kembhavi A A, Bohely P and Barrett A J (1982) Action of rat liver cathepsin $L$ on collagen and other substrates Biochemical Journal 201 367-372 
Knox RV, Zhang Z, Day BN and Anthony RV (1994) Identification of relaxin gene expression and protein localization in the uterine endometrium during early pregnancy in the pig Endocrinology 135 2517-2525

Ko Y, Choi I, Green ML., Simmen FA and Simmen RCM (1994) Transient expression of the cytochrome $\mathrm{P} 450$ aromatase gene in elongating porcine blastocysts is correlated with uterine insulin-like growth factor levels during periimplantation development Molecular Reproduction and Development 37 1-11

La Bonnardiere (1993) Nature and possible functions of interferons secreted by the preimplantation pig blastocyst Journal of Reproduction and Fertility Supplement 48 157-170

Lammer EJ, Chen DT, Hoar RM, Angish ND, Benke PJ, Braun JT, Curry CJ, Fernoff PM, Grix AW, Lott IT, Richard JM and Sun SC (1985) Retinoic acid and embryopathy Netv England Journal of Medicine 313 837-841

Lefevre F and Boulay V (1993) A novel and atypical type one interferon gene expressed by trophoblast during early pregnancy Joumal of Biological Chemistry 268 19760-19768

Letcher R, Simmen RCM, Bazer FW and Simmen FA (1989) lnsulin-like growth factor-1 expression during early conceptus development in the pig Biology of Reproduction 41 1143-1151

Li W, Jaffe RC and Verhage HG (1992) Immunocytochemical localization and messenger ribonucleic acid levels of a progesterone-dependent endometrial secretory protein (cathepsin L) in the pregnant cat uterus Biology of Reproduction 47 21-28

Liu J-P, Baker J, Perkins AS, Robertson EJ and Efstratiadis A (1993) Mice carrying null mutations of the genes encoding insulin-like growth factor I (IGF-1) and Type 1 IGF receptor (IGF1r) Cell 75 59-72

Liu SH, Bartol FF, Two W, Spencer TE and Bazer FW (1995) Expression of keratinocyte growth factor mRNA in porcine endometrium Biology of Reproduction 52 (Supplement 1) 87

Liu SH, Tuo W and Bazer FW (1996) Expression of keratinocyte growth factor receptor mRNA in poncine endometrium Biology of Reproduction 54 (Supplement 1) 76

Malathy P+V, Imakawa K, Simmen RCM and Roberts RM (1990) Molecular cloning of the uteroferrin-associated protein, a major progesterone-induced serpin secreted by the porcine uterus, and the expression of its mRNA during pregnancy Molecular Endocrinology 4 428-440

Margolius HS (1996) Kallikreins and kinins: molecular characteristics and cellular and tissue responses Diabetes 46 S14-S19

Mason RW, Johnson DA, Barrett AJ and Chapman HA (1982) Elastinolytic activity of human cathepsin L Biochemical Journal 233 925-927

Mattson BA, Overstrom EW and Albertini DF (1987) Endodermal cytoskeletal rearrangements during preimplantation pig morphogenesis joumal of Cell Biology 105 257a

Mattson BA, Overstrom EW and Albertini DF (1990) Transitions in trophectoderm cellular shape and cytoskeletal organization in the elongating pig blastocyst Biology of Reproduction 42 195-205

Michel FJ, Fliss MF, Bazer FW and Simmen RC (1992) Characterization and developmental expression of binding sites for the transplacental iron transport protein, uteroferrin, in fetal hematopoictic tissues Biology of the Neonate 61 82-91
Morgan GL, Geisert RD, Zavy MT, Shawley RV and Fazleabas AT (1987) Development of porcine blastocysts in a uterine environment advanced by exogenous oestrogen journal of Reproduction and Fertility 80 125-131

Murray MK, Malanthy PV, Bazer FW and Roberts RM (1989) Structural relationship, biosynthesis and immunocytochemical localization of uteroferrin-associated basic glycoproteins fournal of Biological Chemistry 264 $4143-4150$

Napoli JL, Posch KP, Fiorella PD and Boerman MHEM (1991) Physiological occurrence, biosynthesis and metabolism of retinoic acid: evidence for roles of cellular retinol-binding protein (CRBP) and cellular retinoic acid-binding protein (CRABP) in the pathway of retinoic acid homeostasis Biomedicine Pharmacotherapy 45 131-143

Newton CJ, Buric R, Trapp T, Brockmeier, Pagotto U and Stalla GK (1994) The unliganded estrogen receptor (ER) tranduces growth factor signals Journal of Steroid Biochemistry and Molecular Biology 48 481-486

Nishimura H, Kakizaki l, Muta T, Sasaki N, Pu PX, Yamashita T and Nagasawa $S$ (1995) cDNA and deduced amino acid sequence of human PK-120, a plasma kallikrein-sensitive glycoprotein FEBS Letters 357 207-211

Patten BM (1931) The Embryology of the Pig PP 37-59 P. Blakiston's Son and Co., Philadelphia

Perry JS (1981) The mammalian fetal membranes Journal of Reproduction and Fertility 62 321-335

Pope WF (1994) Embryonic mortality in swine. In Embryonic Mortality in Domestic Species, pp 53-78 Eds RD Geisert and MT Zavy. CRC Press, Boca Raton

Prigent SA and Lemoine NR (1992) The type I (EGF-related) family of growth factor receptors and their ligands Progress in Growth Factor Research 4 1-24

Pusateri AE, Rothschild MF, Wamer CM and Ford SP (1990) Changes in morphology, cell number, cell size and cellular estrogen content or individual littermate pig conceptuses on days 9 to 13 of gestation Journal of Animal Science 68 3727-3735

Renegar RH (1982) An Ultrastructural and Cytochemical Investigation of Endometrium from Pregnant And Nonpregnani Gilts PhD Dissertation, University of Florida, Gainesville

Richoux V, Darribere 'T, Boucaut J-C, Flechon J-E and Thiery J-P (1989) Distribution of fibronectins and laminin in the early pig embryo Anatomical Record 223 72-81

Roberts AB and Spom MB (1988) Transforming growth factorbetas: a large family of multifunctional regulatory proteins Journal of Animal Science 66 (Supplement 3) 67-75

Roberts RM, Bazer FW, Baldwin N and Pollard WE (1976) Progesterone induction of lysozyme and peptidase activities in the porcine uterus Archives of Biochemistry and Biophysics 177 499-507

Roberts RM, Trout WE, Mathialagan N, Stallings-Mann $M$ and Ling P (1993a) Uterine secretory activity and embryo development. In Preimplantation Embryo Development, pp 229-243 Ed. BD Bavister. Springer-Verlag, New York

Roberts RM, Xie S and Trout WE (1993b) Embryo-uterine interactions in pigs during week 2 of pregnancy lournal of Reproduction and Fertility Supplement 48 171-186

Ross AC (1991) Vitamin A: current understanding of the mechanisms of action Nutrition Today 1 6-12

Ross SA, Ahrens RA and De Luca LM (1994) Retinoic acid enhances adhesiveness, laminin and integrin $\beta 1$ synthesis, and retinoic acid receptor expression in F9 teratocarcinoma cells Journal of Cell Physiology 159 263-273 
Rusiniak ME and Black N (1995) Kallikrein-kininogen-kinin system. In Molecular Biology and Biotechnology, pp 483-490 Ed. RE Meyers, VCH Publishers, New York, NY

Saguchi K, Tobe T, Hashimoto K, Sano Y, Nakano Y, Miura N-H and Tomita $M$ (1995) Cloning and characterization of cDNA for inter-trypsin inhibitor family heavy chain-related protein (IHRP), a novel human plasma glycoprotein Journal of Biochemistry 117 14-18

Salier J-P, Darra-Mehrpour M, Sesboue R, Bourguignon J, Benarous R, Ohkubo I, Kurachi S, Kurachi K and Martin JP (1987) Isolation and characterization of CDNAs encoding the heavy chain of human inter-trypsin inhibitor: unambiguous evidence for multipolypeptide chain structure of ITl Proceedings of the National Academy of Sciences USA 84 8272-8276

Salier J-P, Rouet P, Raguenez G and Daveau M (1996) The interinhibitor family: from structure to regulation Biochemical Joumal 315 1-9

Samuel CA and Perry JS (1972) The ultrastructure of the pig trophoblast transplanted to an extopic site in the uterine wall joumal of Anatomy 113 139-149

Sherwood OD (1994) Relaxin. In The Physiology of Reproduction, pp. 861-1009 Eds E Knobil and J Neill, Raven Press, New York, NY

Simmen RCM, Simmen FJ, fliss AE, Smith LC and Fliss MFV (1992a) Ontogeny, immunocytochemical localization, and biochemical properties of the pregnancy-associated uterine elastase/cathepsin-G protease inhibitor, antileukoproteinase (ALP): monospecific antibodies to a synthetic peptide recognize native ALP Endocrinology 130 1957-1965

Simmen FA, Simmen RCM, Geisert RD, Martinat-Botte F, Bazer FW and Terqui $M$ (1992b) Differential expression, during the estrous cycle and pre- and postimplantation conceptus development, of messenger ribonucleic acids encoding components of the pig uterine insulin-like growth factor system Endocrinology 130 1547-1556

Simmen RCM, Ko Y and Simmen FA (1993) Insulin-like growth factors and blastocyst development Theriogenology 39 163-175

Stallings-Mann ML, Burke MG, Trout WE and Roberts RM (1994) Purification, characterization, and cDNA cloning of a kuntz-type proteinase inhibitor secreted by the porcine uterus Journal of Biological Chemistry 269 24090-24094

Stewart CL (1994) Leukaemia inhibitory factor and the regulation of pre-implantation development of the mammalian embryo Molecular Reproduction and Development 39 233-238

Stroband HWJ and Van der Lende T (1990) Embryonic and uterine development during early pregnancy Joumal of Reproduction and Fertility Supplement 40 261-277

Thompson JN, Howell J and Pitt GAJ (1993) Vitamin A and reproduction in rats Proceedings of the Royal Society of London Series B 159 510-535

Tickle C, Lee J and Eichele G (1985) A quantitative analysis of the effect of all-trans-retinoic acid on the pattern of chick wing development Developmental Biology 109 82-95

Tienari J, Alanko T, Lehtonen E and Saksela $O$ (1991) The expression and localization of urokinase-type plasminogen activator and its type 1 inhibitor are regulated by retinoic acid and fibroblastic growth factor in human teratocarcinoma cells Cell Regulation 2 285-297

Trout WE, McDonnell JJ, Kramer KK, Baumbach GA and Roberts RM (1991) The retinol binding protein of the expanding pig blastocyst: molecular cloning and expression in trophectoderm and embryonic disc Molecular Endocrinology 5 1533-1540

Trout WE, McDonnell JJ, Kramer KK, Baumbach GA and Roberts RM (1992) Stemid regulation of the synthesis and secretion of retinol-binding protein by the uterus of the pig Endocrinology 130 2557-2564

Trout WE, Smith GW, Gentry PC, Galvin JM and Keisler DH (1995) Oxytocin secretion by the endometrium of the pig during maternal recognition of pregnancy Biology of Reproduction 52 (Supplement 1) 188

Tuo $W$ and Bazer FW (1996) Expression of fetal fibronectin in porcine conceptuses and uterus throughout gestation Reproduction Fertility and Development $81207-1213$

Tuo W, Harney JP and Bazer FW (1995) Colony-stimulating factor-1 in conceptus and uterine tissues in pigs Biology of Reproduction 53 133-142

Tuo W, Harney JP and Bazer FW (1996) Developmentally regulated expression of interleukin-1 $\beta$ by periimplantation conceptuses in swine foumal of Reproductive Immunology 31 185-198

Valdes G, Figueroa CD and Corthom J (1996) Temperospatial changes of kallikrein-like enzymes during the estrous cycle and pregnancy in the rat uterus Biology of Reproduction 55 236-245

Vallet JL, Christenson RK and McGuire WJ (1996) Association between uteroferrin, retinol-binding protein, and transferrin within the uterine and conceptus compartments during pregnancy in swine Biology of Reproduction 55 1172-1178

Vaughan TJ, James PS, Pascall JC and Brown KD (1992) Expression of the genes for TGF $\alpha$, EGF and the EGF receptor during early pig development Development 116 663-669

Werb Z, Banda MJ and Jones PA (1980) Degradation of connective tissue matrices by macrophages. I. Proteolysis of elastin, glycoproteins and collagen by proteinases isolated from macrophages joumal of Experimental Medicine 152 1340-1357

Wilson EW and Ford SP (1997) Differences in trophectoderm mitotic rate and $P 45017 \alpha$-hydroxylase expression between late preimplantation Meishan and Yorkshire conceptuses Biology of Reproduction 56 380-385

Yelich JV, Pomp D and Geisert RD (1997a) Ontogeny of elongation and gene expression in the carly developing porcine conceptuses Biology of Reproduction 57 1256-1264

Yelich JV, Pomp D and Geisert RD (1997b) Detection of transcripts for retinoic acid receptors, retinol binding protein, and transforming growth factors during rapid trophoblastic elongation in the porcine conceptus Biology of Reproduction 57 126-134

Zhang Z, Krause M and Davis DL (1992a) Epidermal growth factor receptors in porcine endometrium: binding characteristics and the regulation of prostaglandin $E$ and $F_{2 a}$ production Biology of Reproduction 46 932-936

Zhang Z, Paria BC, Dey SK and Davis DL (1992b) Characterization of the epidermal growth factor receptor in preimplantation pig conceptuses Developmental Biology $151617-621$

Zhao M, Yoneda M, Ohashi $Y$, Kurono S, Iwata H, Ohnuki $Y$ and Kimata $K$ (1995) Evidence for the covalent binding of SHAP, heavy chains of inter-trypsin inhibitor, to hyaluronan Journal of Biological Chemistry 270 2665726663 